\title{
The invasive red palm mite, Raoiella indica Hirst (Acari: Tenuipalpidae), in Brazil: range extension and arrival into the most threatened area, the Northeast Region
}

José W. S. Melo, Denise Navia, Jairo A. Mendes, Rosenya M. C. Filgueiras, Adenir V. Teodoro, Joana M. S. Ferreira, Elio C. Guzzo, Izabel V. de Souza, Renata S. de Mendonça, Érica C. Calvet, Antônio A. Paz Neto, Manoel G. C. Gondim Jr, Elisangela G. F. de Morais, Maurício S. Godoy, Jailma R. dos Santos, Raimundo I. R. Silva, Valesca B. da Silva, Rhenan F. Norte, Antônio B. Oliva, Robson D. P. dos Santos \& Cleiton A. Domingos

To cite this article: José W. S. Melo, Denise Navia, Jairo A. Mendes, Rosenya M. C. Filgueiras, Adenir V. Teodoro, Joana M. S. Ferreira, Elio C. Guzzo, Izabel V. de Souza, Renata S. de Mendonça, Érica C. Calvet, Antônio A. Paz Neto, Manoel G. C. Gondim Jr, Elisangela G. F. de Morais, Maurício S. Godoy, Jailma R. dos Santos, Raimundo I. R. Silva, Valesca B. da Silva, Rhenan F. Norte, Antônio B. Oliva, Robson D. P. dos Santos \& Cleiton A. Domingos (2018) The invasive red palm mite, Raoiella indica Hirst (Acari: Tenuipalpidae), in Brazil: range extension and arrival into the most threatened area, the Northeast Region, International Journal of Acarology, 44:4-5, 146-149, DOI: 10.1080/01647954.2018.1474945

To link to this article: https://doi.org/10.1080/01647954.2018.1474945

曲 Published online: 04 Jun 2018.

山ll Article views: 89
Submit your article to this journal $₫$

View Crossmark data [ᄌ 


\section{The invasive red palm mite, Raoiella indica Hirst (Acari: Tenuipalpidae), in Brazil: range extension and arrival into the most threatened area, the Northeast Region}

José W. S. Meloa, Denise Naviab ${ }^{b}$ Jairo A. Mendesa, Rosenya M. C. Filgueirasa, Adenir V. Teodoroc, Joana M. S. Ferreirac, Elio C. Guzzoc, Izabel V. de Souza ${ }^{d}$, Renata S. de Mendonça ${ }^{e}$, Érica C. Calvet ${ }^{f}$, Antônio A. Paz Netof, Manoel G. C. Gondim Jrf, Elisangela G. F. de Morais ${ }^{\mathrm{g}}$, Maurício S. Godoy ${ }^{\mathrm{h}}$, Jailma R. dos Santos', Raimundo I. R. Silva', Valesca B. da Silvah, Rhenan F. Nortei, Antônio B. Olivaj, Robson D. P. dos Santosj and Cleiton A. Domingosk

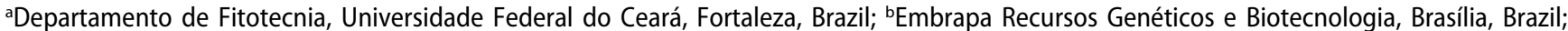
'Embrapa Tabuleiros Costeiros, Aracaju, Brazil; dInstituto Federal de Alagoas, Maceió, Brazil; eDepartamento de Fitossanidade, Universidade de Brasília, Brasília, Brazil; fDepartamento de Agronomia, Universidade Federal Rural de Pernambuco, Recife, Brazil; ${ }^{\circ}$ Embrapa Roraima, Boa Vista, Brazil; ' 'Departamento de Ciências Agronômicas e Florestais, Universidade Federal Rural do Semi-Árido, Mossoró, Brazil; 'Instituto Federal de Educação, Ciência e Tecnologia do Ceará, Limoeiro do Norte, Brazil; 'Agência de Defesa Agropecuária da Bahia, Salvador, Brazil; 'knstituto Federal do Piauí, Paulistana, Brazil

\section{ABSTRACT}

Raoiella indica Hirst (Acari: tenuipalpidae), commonly known as the red palm mite (RPM), is an invasive polyphagous pest, which has emerged as a threat to agriculture in the Americas. In the Americas, the mite has not only spread quickly, but also greatly extended its host range in the new areas where it has been observed. We present here new records of the RPM in Brazilian states, with focus on its arrival into the most threatened area, the Northeast Region. Coconut and banana are important crops in this region of Brazil and represent the main threatened crops by this pest. These new records of RPM reinforce the idea that this species is already widely distributed throughout Brazil eight years after its introduction into the extreme North state of Roraima. Comments on the possible economic, social and environmental impacts are presented.

\section{ARTICLE HISTORY}

Received 27 February 2018 Accepted 6 May 2018

Published online 4 June 2018

\section{KEYWORDS}

Invasive mite pest: Neotropics; South America; coconut; palm trees; banana

\section{Introduction}

Invasive species represent one of the most serious threats to biodiversity worldwide (Pimentel 2011; Funk 2015), with impacts on non-native habitats potentially having negative ecosystem effects (Gurevitch and Padilla 2004) and strong economic burden (Pimentel et al. 2005). Phytophagous mites are prone to becoming invasive as they are difficult to detect, have a capacity to survive adverse conditions, some have parthenogenic reproduction and may adapt to new host plants. Some may become pests due to their harm to host plants, vectoring of disease and fast development of pesticide resistance (Navia et al. 2007).

A notable and recent example of a phytophagous mite species that has become an invasive pest is the red palm mite (RPM) Raoiella indica Hirst (Acari: Tenuipalpidae). RPM was described from specimens collected from coconut (Cocos nucifera L.) in Southern India (Hirst 1924) and found later on other palms (Arecaceae) in several African, Asian and Middle Eastern countries (Mesa et al. 2009). Since its description, the distribution of the RPM remained restricted to the Old World, until it was found damaging coconut palms on the Caribbean island of Martinique in 2004 (Flechtmann and Etienne 2004). Afterwards, RPM was found in other Caribbean Islands (Etienne and Fletchmann 2006; Rodrigues et al. 2007), North America (USA and Mexico; Welbourn 2006; Estrada-Venegas et al. 2010; Kane et al. 2012) and South America (Venezuela, Colombia and Brazil; Vasquez et al. 2008; Carrillo et al. 2011; Navia et al. 2011). In the New World, RPM has not only reached large populations and spread quickly, but it also greatly extended its host range, attacking several palm species (Arecaceae) and a number of Cannaceae, Cycadaceae, Heliconiaceae, Musaceae, Strelitziaceae and Zingiberaceae species, including exotic and native plants, in cultivated or natural areas (Cocco and Hoy 2009; Lima et al. 2011; Gondim et al. 2012; Carrillo et al. 2012a; Navia et al. 2015).
In contrast to other Raoiella species, RPM is highly invasive, show rapid dispersal capabilities and feed on monocot hosts (mainly palms), whereas other species are known only from a very restricted host range (feed on dicots; in particular, species in the family Myrtaceae) within a single country (Ochoa et al. 2011; Dowling et al. 2012). Invasion of new areas by RPM is favoured by its high population growth within a broad range of temperatures (Moutia 1958). Owing to an arrhenotokous mode of parthenogenesis (males developing from unfertilized eggs), a small number of individuals or even a single female may initiate a new colony that can build up rapidly as a result of several typical "r-selected" traits including short generation time (Sabelis 1985) and high dispersal ability (Hoy et al. 2006; Welbourn 2006). In addition, because of its small size (eggs are 100 microns long and 80 microns wide while adults are about 245 microns long and 182 microns wide (Hirst 1924; Moutia 1958), RPM can be difficult to detect on plants and may remain undetected in new localities until its presence is revealed by outbreaks and plant symptoms.

Among the host plants infested by the RPM, coconut and bananas seem to be the most threatened (Peña et al. 2010; Navia et al. 2013). In Trinidad and Tobago, some growers have reported $70 \%$ losses to coconut production (unpublished information of Philippe Agostine, President of Trinidad and Tobago Growers Association, reported by Roda et al. 2012). There are no data on banana production loss due to RPM attacks; however, in some localities, e.g. Dominican Republic, Trinidad and Tobago and Colombia, this crop has been seriously affected as several basal leaves have died completely and mature leaves have become completely chlorotic (Navia et al. 2013).

In Brazil, RPM was first reported in samples from coconut and banana leaves from the urban area of Boa Vista, the capital of the 
northern state of Roraima in 2009 (Navia et al. 2011). Authorities from the Brazilian Ministry of Agriculture, Livestock and Food Supply (MAPA) established quarantine measures restricting the movement of plant material and products (banana and coconut fruits) from infested areas to other states. However, these measures failed to prevent the spread of RPM to the urban area of Manaus, the capital of neighbouring Amazonas state, two years later (Rodrigues and Antony 2011). Because of its occurrence in Roraima and Amazonas states, the status of RPM was changed in 2013 from a quarantine pest not present to a quarantine pest present with restricted distribution in Brazil, allowing other states to adopt measures to prevent its arrival. For about five years, the distribution of RPM remained restricted to Northern Brazil. Nevertheless, recent reports on RPM in São Paulo (Southeastern) (Oliveira et al. 2016) and Paraná (Southern) (Hata et al. 2017) showed that it has spread to other regions of Brazil.

Here, we present: (i) eleven new records of the RPM in Brazilian states; and (ii) discussion on the dispersal pathways of RPM in Brazil.

Despite governmental efforts and warnings made by researchers, the RPM has reached Northeast Brazil. In 2016, examination of coconut leaflets and banana leaves confirmed for the first time the presence of RPM in the Northeast region (Ceará state). After a few months, this invasive mite pest was also detected in 10 other states [7 in Northeastern Brazil (Alagoas, Bahia, Paraíba, Pernambuco, Piauí, Rio Grande do Norte and Sergipe), 2 in Midwestern Brazil (Distrito Federal and Goiás) and 1 in SouthEastern Brazil (Minas Gerais) (Figure 1 and Table 1)]. All RPM developmental stages and numerous exuviae were observed in the new records for all host plants, except for oil palm plants
(Elaeis guineensis). For this host, small adult colonies were observed. According to Gómez-Moya et al. (2017), E. guineensis in not considered a typical host for the RPM. Hence, it is probable that its occurrence in this plant species is casual. We found typical host plants (Heliconia sp., Phoenix sp., Roystonea sp.) growing near the $E$. guineensis plants. After each detection, a memorandum documenting presence of the RPM was sent to the Plant Health Service of MAPA, at each state, to prompt the adoption of appropriate measures.

Under natural conditions, RPM long-distance dispersal is probably by wind as for other plant-feeding mites (Welbourn 2006). However, the great distance between previously infested areas in Brazil - North and Southeast regions - and from these regions to the Northeast suggests that spread of RPM via natural dispersion alone is unlikely and that the pest reached new regions by transportation of host plants or infected plant material.

Brazil is the third and fourth largest producer of coconut and banana, respectively (FAO 2017). The major coconut-producing area lies in the Northeast region while the banana production areas are scattered across the country (IBGE 2016). The Northeast region comprises about $81 \%(219,472$ ha) of the coconut area in Brazil: the state of Bahia is the main producer, with $28 \%$ of the coconut production area; followed by Ceará, with 16.5\%; Sergipe, with 14.4\%; Rio Grande do Norte, with $8 \%$; Alagoas, with 4.7\%; Pernambuco, with $4 \%$ and Paraíba, with 3.5\% (IBGE 2016). Banana production in Brazil accounts for approximately $10 \%$ of the entire world and the main producer in Brazil is in the southeastern state of São Paulo. Other notable areas where bananas are cultivated include Bahia, Ceará and Pernambuco in North-East Brazil; Para in North Brazil; Minas

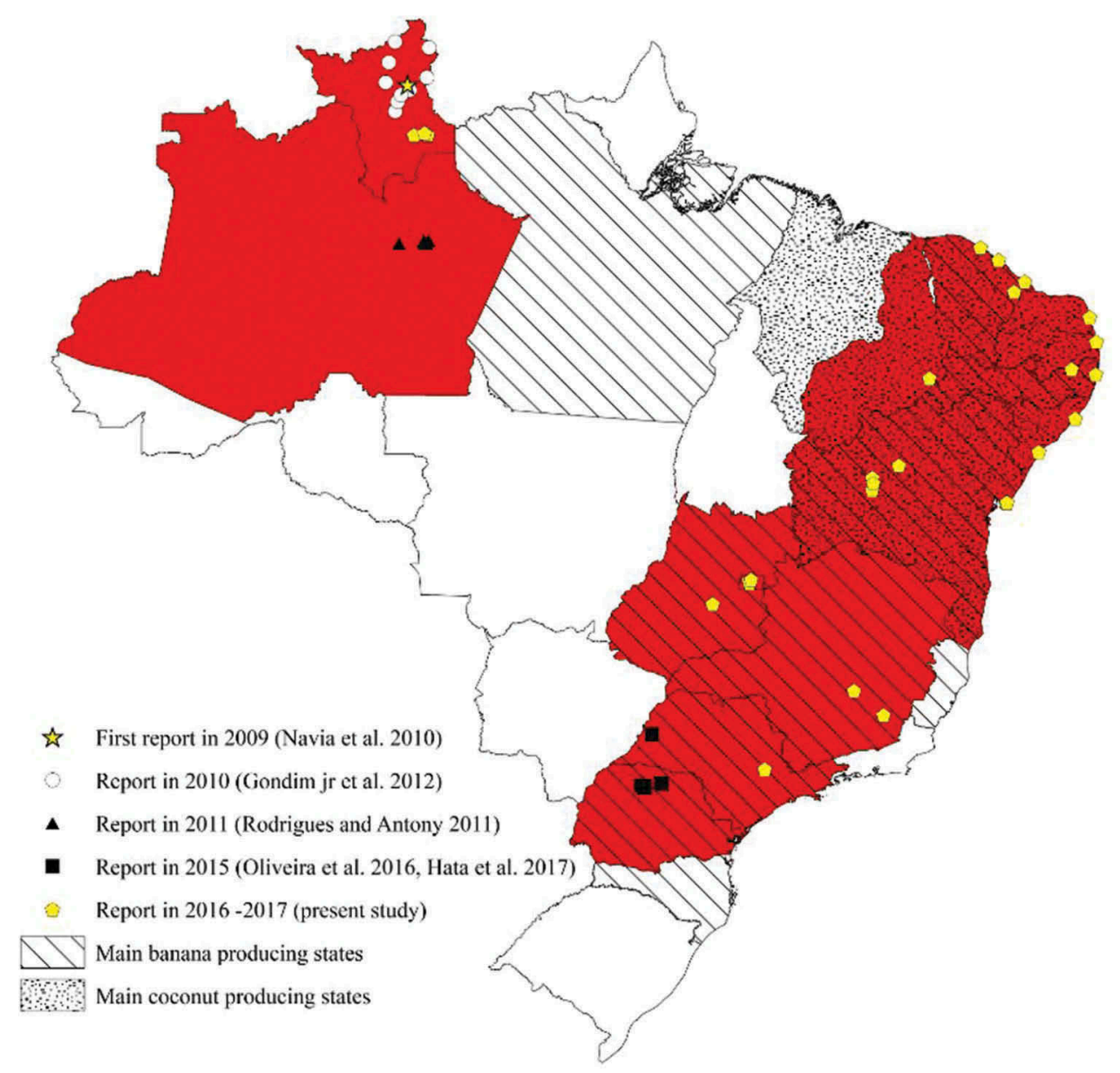

Figure 1. Current red palm mite distribution in Brazil. 


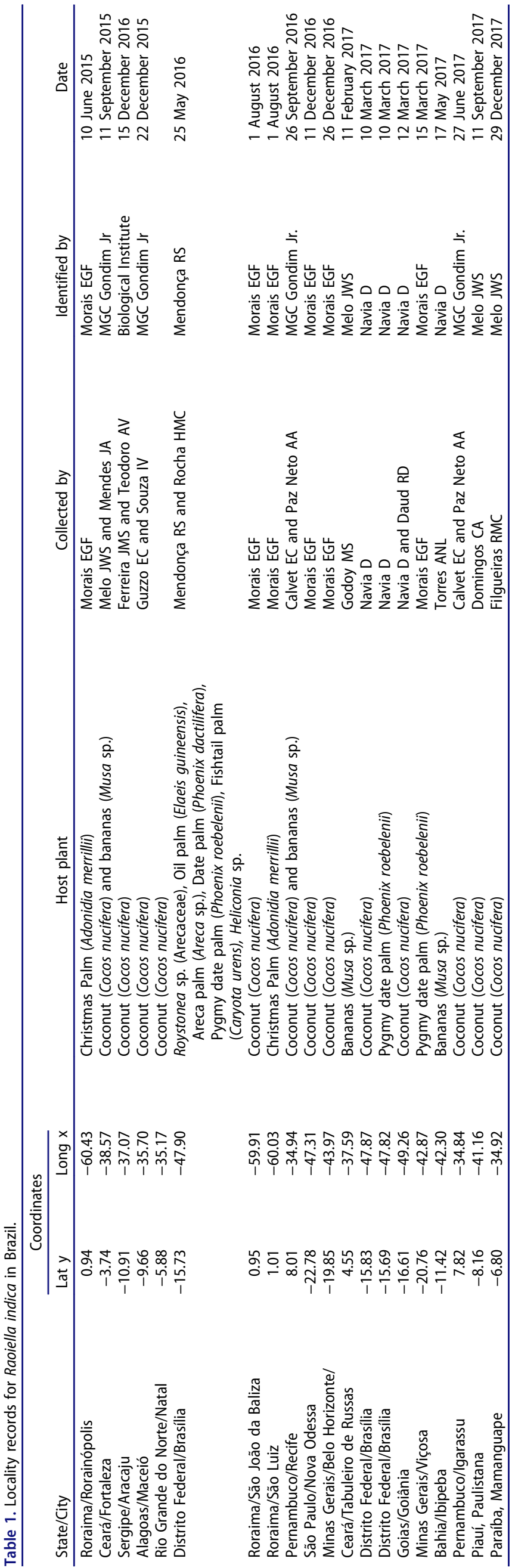

Gerais and Espirito Santo in South-Eastern Brazil; Santa Catarina and Paraná in the southern Brazil and Goias in Midwestern Brazil (IBGE 2016).

Since Northeast of Brazil is characterized by low rainfall and high temperatures, which are favourable conditions for the development of RPM (Nagesha-Chandra and Channabasavanna 1983; Taylor et al. 2012), the arrival of this pest in this region has the potential to cause heavy economic losses as well as social and cultural disturbance. Navia et al. (2016) conducted a study to predict the spatial distribution of RPM in Brazil under current and future climate change scenarios. The prediction maps showed that Brazil presents extensive areas with favourable conditions for the establishment of RPM, especially in northeastern Brazil. An increasing favourability is predicted for future scenarios indicating that the pest impact will worsen with higher RPM populations and a wider distribution within the country.

Economic, social and environmental impacts are expected following a wider distribution of RPM in Brazil. Significant losses to agriculture may occur due to the potential damage of RPM to plants of economic importance, such as coconut, banana, several species of palm-producing oil or wax, and ornamental plants. Quarantine measures may also lead to economic losses, prohibiting the transportation of propagation material or fresh products of RPM host plants from infested to uninfested areas/countries. Social impacts are expected since many smallholders are engaged in the production or extraction of palm products. Environmental impacts are also possible due to RPM colonization of native plants that have an important role in natural ecosystems.

Biological control has been considered the most promising strategy to minimizing impact of this invasive mite pest in Brazil. Although some natural enemies have been introduced for RPM control in Brazil (Moraes et al. 2012; Oliveira 2015), and others have been observed associated with the pest (Carrillo et al. 2012b), an efficient biological control strategy still needs to be defined and research should be intensified for this purpose.

\section{Disclosure statement}

No potential conflict of interest was reported by the authors.

\section{References}

Carrillo D, Amalin D, Hosein F, Roda A, Duncan RE, Penã JE. 2012a. Host plant range of Raoiella indica (Acari: Tenuipalpidae) in areas of invasion of the new world. Experimental \& Applied Acarology. 57:271-289.

Carrillo D, Frank JH, Rodrigues JCV, Peña JE. 2012b. A review on the natural enemies of the red palm mite, Raoiella indica (Acari: Tenuipalpidae). Experimental \& Applied Acarology. 57:347-360.

Carrillo D, Navia D, Ferragut F, Penã JE. 2011. First report of Raoiella indica (Acari: Tenuipalpidae) in Colombia. Florida Entomologist. 94:370-371.

Cocco A, Hoy MA. 2009. Feeding, reproduction, and development of the red palm mite (Acari: Tenuipalpidae) on selected palms and banana cultivars in quarantine. Florida Entomologist. 92:276-291.

Dowling APG, Ochoa R, Beard JJ, Welbourn WC, Ueckermann EA. 2012. Phylogenetic investigation of the genus Raoiella (Prostigmata: Tenuipalpidae): diversity, distribution, and world invasions. Experimental \& Applied Acarology. 57:257-269.

Estrada-Venegas E, Martinez-Morales H, Villa-Castillo J. 2010. Raoiella indica Hirst (Acari: Tenuipalpidae): first record and threat in Mexico. In: de Moraes GJ, Castilho RC, Flechtmann CHW, editors. Abstract book: XIII international congress of acarology. Recife. p. 23-27. Oakland, CA: Magnolia Press

Etienne J, Fletchmann CHW. 2006. First record of Raoiella indica (Hirst, 1924) (Acari: Tenuipalpidae) in Guadeloupe and Saint Martin, West Indies. International Journal Acarol. 32:331-332. 
[FAO] Food and Agriculture Organization of the United Nations. 2017. World production. [accessed 2017 Jun 12]. http://faostat. fao.org/site/339/default.aspx.

Flechtmann CHW, Etienne J. 2004. The red palm mite, Raoiella indica Hirst, a threat to palms in the Americas (Acari: Prostigmata: Tenuipalpidae). Systems Applications Acarology. 9:109-110.

Funk JL. 2015. Invasive species: a global problem in need of a global solution. Bio Sciences. 65:623-624.

Gómez-Moya C, Lima TPS, Morais EGF, Gondim MGC Jr, Moraes GJ. 2017. Hosts of Raoiella indica Hirst (Acari: Tenuipalpidae) native to the Brazilian Amazon. Journal of Agricultural Science. 9:86-94.

Gondim MGC Jr, Castro TMMG, Marsaro Junior AL, Navia D, Melo JWS, Demite PR, Moraes GJ. 2012. Can the red palm mite threaten the Amazon vegetation? Systems Biodiversity. 10:527-535.

Gurevitch J, Padilla DK. 2004. Are invasive species a major cause of extinctions? Trends in Ecology \& Evolution. 19:470-474.

Hata FT, Silva JEP, Ventura MU, Pasini A, Roggia S. 2017. First report of Raoiella indica (Hirst) (Acari: Tenuipalpidae) in southern Brazil. Neotropical Entomology. 46:356-359.

Hirst S. 1924. On some new species of red spiders. Annals and Magazine of Natural History. 14:522-527.

Hoy MA, Peña J, Nguyen R 2006. The red palm mite. Featured creatures. [accessed 2017 Jun 2]. http://entnemdept.ifas.ufl. edu/creatures/orn/palms/red_palm_mite.htm.

[IBGE] Instituto Brasileiro de Geografia e Estatística. 2016. Levantamento sistemático da produção agrícola: pesquisa mensal de previsão e acompanhamento das safras agrícolas no ano civil. [accessed 2017 Jun 7]. ftp://ftp.ibge.gov.br/Producao_ Agricola/Levantamento_Sistematico_da_Producao_Agricola_ [mensal]/Fasciculo/2016/lspa_201612_20170222_133000.pdf.

Kane EC, Ochoa R, Mathurin G, Erbe EF, Beard JJ. 2012. Raoiella indica (Acari: Tenuipalpidae): an exploding mite pest in the neotropics. Experimental \& Applied Acarology. 57:215-225.

Lima MR, Rodriguez H, Gonzalez Al, Gonzalez M. 2011. Management strategy of Raoiella indica Hirst (Acari: Tenuipalpidae) in Cuba. Zoosymposia. 6:152-159.

Mesa NC, Ochoa R, Welbourn WC, Evans GA, Moraes GJ. 2009. A catalogue of the Tenuipalpidae (Acari) of the world with a key to genera. Zootaxa. 2098:1-185.

Moraes GJ, Castro TMMG, Kreiter S, Quilici S, Gondim MGC Jr, Sá LAN. 2012. Search for natural enemies of Raoiella indica Hirst in La Reunion Island (Indian Ocean). Acarologia. 52:129-134.

Moutia LA. 1958. Contribution to the study of some phytophagous acarina and their predators in Mauritius. Bulletin of Entomological Research. 49:59-75.

Nagesha-Chandra BK, Channabasavanna GP. 1983. Studies on seasonal fluctuation of the population of Raoiella indica (Acari: Tenuipalpidae) on coconut with reference to weather parameters. Indian Journal of Acarology. 8:104-111.

Navia D, Hamada E, Gondim MGC Jr, Polo BN. 2016. Spatial forecasting of red palm mite in Brazil under current and future climate change scenarios. Pesquisa Agropecuária Brasileira. 51:586-598.

Navia D, Marsaro AL Jr, da Silva FR, Gondim MGC Jr, de Moraes GJ. 2011. First report of the red palm mite, Raoiella indica Hirst (Acari: Tenuipalpidae), in Brazil. Neotropical Entomology. 40:409-411.

Navia D, Marsaro AL Jr, Gondim MGC Jr, Mendonça RS, Pereira PRVS. 2013. Recent mite invasions in South America. In: Peña J, editor. Potential invasive pests of agricultural crops. Boston: CAB International. p. 251-287.
Navia D, Moraes GJ, Flechtmann CHW. 2007. Phytophagous mites as invasive alien species: quarantine procedures. In: Morales-Malacara JB, Behan-Pelletier V, Ueckermann E, Perez TM, Estrada-Venegas EG, Badii M, editors. Acarology XI: proceedings of the International Congress. Merida (Mexico): Instituto de Biologia and Facultad de Ciencias, Universidad Nacional Autonoma de Mexico, Sociedad Latino americana de Acarologia. p. 307-316.

Navia D, Morais EGF, Mendoça RS, Gondim MGC Jr. 2015. Ácaro vermelho-das-palmeiras, Raoiella indica Hirst. In: Vilela EF, Zucchi RA, editors. Pragas introduzidas no Brasil: Insetos e ácaros. Piracicaba: ESALQ/USP. p. 418-452.

Ochoa R, Beard JJ, Bauchan GR, Kane EC, Dowling APG, Erbe EF. 2011. Herbivore exploits chink in armour of host. American Entomology. 57:26-29.

Oliveira DC 2015. Exploration of potential agents for the biological control of the red palm mite, Raoiella indica Hirst (Acari: Tenuipalpidae), on coconut palms in Brazil [PhD Thesis]. Piracicaba: Escola Superior de Agricultura Luiz de Queiroz, Universidade de São Paulo.

Oliveira DC, Prado EP, Moraes GJ, Morais EGF, Chagas EA, Gondim MGC Jr, Navia D. 2016. First report of Raoiella indica (Acari: Tenuipalpidae) in southeastern Brazil. Florida Entomologist. 99:123-125.

Peña JE, Carrillo D, Rodrigues JCV, Roda A. 2010. El ácaro rojo de las palmas, Raoiella indica (Acari: Tenuipalpidae), una plaga potencial para América Latina. In: Sánchez Gálvez MC, Sandoval-Islas JS, Estrada-Venegas EGE, editors. Primer Simposio Internacional de Acarología en México - memorias. Chapingo: Universidad Autónoma Chapingo. p. 48-57.

Pimentel D. 2011. Biological invasions: economic and environmental costs of alien plant, animal, and microbe species. Boca Raton: CRC Press.

Pimentel D, Zuniga R, Morrison D. 2005. Update on the environmental and economic costs associated with alien-invasive species in the United States. Ecological Economics. 52:273-288.

Roda A, Nachman G, Hosein F, Rodrigues JCV, Peña JE. 2012. Spatial distributions of the red palm mite, Raoiella indica (Acari: Tenuipalpidae) on coconut and their implications for development of efficient sampling plants. Experimental \& Applied Acarology. 57:291-308.

Rodrigues JCV, Antony LMK. 2011. First report of Raoiella indica (Acari: Tenuipalpidae) in Amazonas state, Brazil. Florida Entomologist. 94:1073-1074.

Rodrigues JCV, Ochoa R, Kane EC. 2007. First report of Raoiella indica Hirst (Acari: Tenuipalpidae) and its damage to coconut palms in Puerto Rico and Culebra Island. International Journal Acarol. 33:3-5.

Sabelis MW. 1985. Reproductive strategies. In: Helle W, Sabelis MW, editors. Spider mites, their biology, natural enemies and control. Amsterdam: Elsevier. p. 265-278.

Taylor B, Rahman PM, Murphy ST, Sudheendrakumar VV. 2012. Within-season dynamics of red palm mite (Raoiella indica) and phytoseiid predators on two host palm species in south-west India. Experimental \& Applied Acarology. 57:331-345.

Vasquez C, Quiros MG, Aponte O, Sandoval DMF. 2008. First report of Raoiella indica Hirst (Acari: Tenuipalpidae) in South America. Neotropical Entomology. 37:739-740.

Welbourn C 2006. Pest alert. Red palm mite Raoiella indica Hirst (Acari: Tenuipalpidae). [accessed 2017 Jun 12]. http://www. freshfromflorida.com/content/download/66454/1601562/Pest_ Alert_Raoiella_indica,_Red_palm_mite.pdf. 